\title{
The Fragile Strength of a Dissolving Subjectivity
}

José A. Zamora

Krisis 41 (2): 60-62.

DOI

$10.21827 /$ krisis. 41.2 .38242

\section{Licence}

This work is licensed under a Creative Commons Attribution 4.0 License International License (CC BY 4.0). (C) 2021 The author(s). 


\section{The Fragile Strength of a Dissolving Subjectivity}

José A. Zamora

As a man who, by rights, should have been put to death, and according to whom it was only by chance that he escaped the extermination perpetrated by the National Socialists, he felt "the drastic guilt of him who was spared." This feeling was born of the inevitable complicity of the survivor and the basic principle of bourgeois subjectivity that made such extermination possible in the first place: coldness. In this respect, Adorno had no doubts: one cannot continue to live if the enormous suffering brought about by catastrophe is constantly borne in mind. To continue reproducing one's own existence under the conditions established by capitalist socialization demands coldness in the face of the suffering of those who were annihilated. Such coldness is not simply an attribute of certain individuals, but rather, it is an objective principle of social relations under which all the members of capitalist society reproduce their existence.

Therefore, when rethinking the linkage between subjectivation and suffering, we must not overlook the fact that Adorno writes not about the damaged life but, rather, from it. In Minima Moralia it is not the sovereign subject, master both of his own will and ability to know, who pontificates on the just life. Rather, it is a subject who is doubly wounded by the violence of the barbarity that blighted Europe and by the keen awareness of the dehumanizing cost of continuing to live during and after the catastrophe. In other words, it is a subject that acknowledges the impossibility of leading a just life in the wrong and who therefore recognizes that it is no longer possible to experience the truth about life other than by confronting its alienated form; that is, confronting "the objective powers that determine individual existence even in its most hidden recesses" ("Dedication").

Indeed, thought becomes paralyzed when faced with such an unfolding of effective destruction, one that even assumes the irrational price of ultimate self-destruction. Furthermore, many of the great ideas of enlightenment modernity pale in the face of such destruction: reason, the subject, autonomy, emancipation, and progress. The reversal of means and ends that undermines the enlightened imperative of treating individuals as ends themselves, which, within this tradition, could nevertheless be criticized and countered, reveals the absurdity of the process of capitalist modernization which consummates this reversal by transforming life into an ephemeral apparition. Before such a process, naivety is no longer possible. Barbarity is not the other in relation to this process. Rather, barbarity's roots are buried in that process and its contradictions. This fact requires a radical self-critique of enlightened modernity and its fundamental figures of self-understanding. First, the idea of the subject, which in itself is an exemplary compendium of the signal ideas of said modernity; all of Adorno's efforts to radically critique modern subjectivation and subjectivity are motivated by the experiences of barbarity that blight the twentieth century. Such experiences drive him to attempt to unravel not only the processes that constitute this specific subjectivity, but also the ties that bind the crushing objectivity of the historical dynamic and the dissolution of the subject, ties that became absolute in the extermination camps but was never limited to the camps. 
Throughout Minima Moralia, Adorno repeatedly reflects on the conditions of possibility of an inquiry into the subject's experience of dissolution, which itself is necessarily aporetic. This moment of reflection is aporetic because even if one lacks any intention of doing so, in its unfolding one reproduces the illusion of the same subject that questions its own existence in light of its experience of self-annihilation. For this reason, such reflection cannot simply surrender itself to the immediacy of an apparently authentic subjective experience, disregarding the objective mediation that constitutes and transcends it. However, neither is there some theoretical understanding of objectivity that dissolves the "subject" form without the painful experience of the individual who has been emptied of this substance, one which can only come from non-antagonistic objectivity, from a place free of coercion. Following Hegel's intention and not his bias in favour of a false totality over and against the singular, Adorno considers precisely that which disappears as essential in perceiving the true character of the false totality. Recognition of the primacy of an antagonistic totality, of the objective tendency that manifests itself in the annihilation of the individual, its effective ally, prohibits its reification and, all the more, the glorification of a universality whose negativity is accessible only through the individual experience of the coercion and domination that ruin his life.

The point of intersection between antagonistic objectivity and individual experience is suffering, the "objectivity that weighs upon the subject; its most subjective experience, its expression, is objectively mediated" (Adorno 1973, 17-18). Hence, for Adorno, the two poles - individual experience and a critical theory of society-claim each other, without the tension between them disappearing and without either one being able to do without the other at any time. Theory that intends to articulate a critical self-awareness of reified social relations, which are objectified and almost closed off to theoretical and practical questioning, must feed on subjective experience. However, this experience needs this very same theory if it is to become an undiminished, unadministered experience. This collaboration is possible because it involves an experience that develops from its object as a contradictory and dynamic object and which, precisely for this reason, is not purely subjective and insubstantial: the experience gathers in itself all the burden of objectivity that courses through it, and as soon as it is mediated by the rationality that informs this objectivity it makes possible its theoretical approach, namely the work of the concept. Regardless of how weakened it became, for Adorno, the possibility of experiencing in itself the coercive force that individuals suffer in a society marked by the tendency to total socialization had never been suppressed. Furthermore, he never lost trust in the possibility that the content of that experience could emerge in the interpretation of social and cultural phenomena. It is precisely upon such content that the theory of social objectivity should draw. 


\section{References}

Adorno, Theodor W. 1973. Negative Dialectics. London and New York: Routledge.

\section{Biography}

José A. Zamora is a Senior Researcher at the Institute of Philosophy (Spanish Higher Council for Scientific Research - CSIC), Madrid-Spain. $\mathrm{PhD}$ (Münster/Germany). His research lines are Critical Theory (Th.W. Adorno, W. Benjamin), Social Suffering, Authoritarianism, Philosophy after Auschwitz, Political Theologies of Modernity. Main publications: Krise -Kritik -Erinnerung. Ein politisch-theologischer Versuch über das Denken Adornos im Horizont der Krise der Moderne [Crisis Critique - Memory. A political-theological attempt about Adorno's thinking in the horizon of the crisis of modernity] (1995), Th.W. Adorno: Pensar contra la barbarie [Th. W. Adorno: Thinking against Barbarism] (2004; port. 2008) and La crisis y sus victimas [The crisis and its victims] (2014). He chairs the "Sociedad de Estudios de Teoría Crítica» and is editor of Constelaciones. Revista de Teoría Crítica. 